\title{
WHAT ARE THE PROPER GROUNDS FOR GRANTING ANNULMENTS?
}

\author{
ROBERT KINGSLEY*
}

Fundamentally, the law of annulment is a specialized branch of the law of rescission of contracts. Without here entering into any debatement over whether or not marriage is only a civil contract, ${ }^{1}$ it is clear that it is a status ${ }^{2}$ which is created by contract; and it is also true that, in broad terms, the requisites of marriage are those of any civil contract-that is, there must be parties capable of contracting, who must evidence their consent in an appropriate manner. It is, of course, to the law of marriage, rather than to the law of annulment, that we turn for the answers to many of the fundamental problems that face us, for it is that law which decrees who is capable of contracting marriage, and it is that law which decrees the formalities by which consent must be evidenced.

The several standard grounds for annulment (without now distinguishing between annulment of voidable marriages and declaratory decrees of nullity of void marriages) fall into two groups: (I) Those concerned with the existence and manifestation of consent, and (2) those concerned with the personal capability for marriage of the parties.

\section{I}

\section{Consent to Marry}

In order to have a valid marriage: (I) the parties must intend to enter into the marriage status; and (2) their intent to be married must have been acquired, and must exist, as a "voluntary" state of mind.

While the cases of Error, Mistake, and Jest are individually interesting, and while the courts have shown some difficulty in analysis of border-line situations, ${ }^{3}$ still the chief problem in connection with the existence of an intent to marry has been in those cases where the ability to form such an intent was in question-i.e., cases of so-called "Insanity" and of Intoxication.

In determining whether or not a party to a marriage ceremony was mentally com-

- A.B. and A.M. I923, LL.B. 1926, University of Minnesota; S.J.D. 1928, Harvard University. Dean, School of Law, University of Southern California. Author of sundry articles on Domestic Relations.

${ }^{2}$ Cf. Editorial, 23 CENT. L. J. 289 (1886); Gatto v. Gatto, 79 N. H. I77, 106 Atl. 493 (1919); Ex parte Suzanna, 295 Fed. 7r3, 7r4-715 (D. Mass. r924); State v. Fry, 4 Mo. I20, I80-187 (1835). ${ }^{2}$ Consult Note, 2 ALA. L. J. 266 (I927).

a Compare the varying results reached in: Crouch v. Wartenberg, 86 W. Va. 664, I04 S.E. II7 (I920), gr W. Va. 9I, II2 S.E. 234 (I922), discussed in Notes, 29 W. VA. L. Q. 60 (I922) and 21 CoL. L. Rev. I94 (192I); Stone v. Stone, I59 Fla. 624, 32 So. $2 \mathrm{~d} 278$ (1947), noted in 19 U. of PrTT. L. Rev. 277 (1948); Schibi v. Schibi, 136 Conn. I96, 69 A. 2d 83 I (1949), discussed in Note, 31 OrE. L. Rev. 256 (1952); United States v. Rubenstein, I5I F. 2d I74 (2d Cir. 1945); United States. v. Lutwak, I95 F. 2d 748 (7th Cir. 1952). 
petent to give a legally binding consent to become married, the courts have used a wide variety of language. A few courts have said that the issue was whether or not the party was mentally capable of entering into an ordinary commercial contract; ${ }^{4}$ but the later cases have held that there is no necessary connection between the capacity to make commercial contracts and the capacity to become married.5 The test today is usually put as requiring the mental ability to "understand the nature of the marriage relation and the duties and obligations involved therein." So put, it is clear that the capacity to enter into business relations has no bearing

- Inhab. of Atkinson v. Inhab. of Medford, 46 Me. 510 (1859); Inhab. of Middleborough v. Inhab. of Rochester, 12 Mass. (12 Tyng) 363 (1815); Anonymous, 21 Mass. (4 Pick.) 32 (1826); Cole v. Cole, 37 Tenn. (5 Sneed) 57, 70 Am. Dec. 275 (1857); see: Sibley v. Kennedy, 224 Ala. 354, I 40 So. 552 (1932); Dunphy v. Dunphy, 16x Cal. 380, II9 Pac. 512 (I911), discussed in Note, 10 Mick. L. Rev. 500 (1912).

5 "Perhaps the same degree of mental strength is not required as is essential in the transaction of business, involving the exercise of judgment, reason, and experience sufficient to cnable the party to compete with an antagonist designing to obtain an advantage and to protect his own interests, yet he must be capable of entering understandingly into the relation of marriage." Hagenson v. Hagenson, 258 Ill. 197, 199, xo1 N.E. 606, 607 (1913).

“. . . the same mental strength necessary to the transaction of business is not necessary to cnable the party to contract a marriage, though he must be capable of understanding the nature of the act. . . ." Flynn v. Troesch, 373 Ill. 275, 292-293, 26 N.E. 2d 9I, 99 (x940).

Accord: Johnson v. Johnson, $21_{4}$ Minn. 462, 8 N.W. $2 d$ 620 (1943); Payne v. Burdette, 84 Mo. App. 332 ( 1900 ) (holding that adjudication of insanity in a lunacy proceeding was not conclusive on the issue of capacity to marry); McCleary v. Barcalow, 6 Ohio C.C. $48 \mathrm{r}, 3$ Ohio Dec. 547 (189r) (semble); Ross v. Ross, 175 Okla. 663, 54 P. 2 d 6II (1936); Ex parte Chace, 26 R.I. 35I, 58 Atl. 978 (1904); Roether v. Roether, 180 Wis. 24, I9I N. W. 576 (1923); sec: Imhoff v. Witmer's Adm'r, 31 Pa. St. (7 Casey) 243 ( 1858 ).

".. . we take it that the question of what is an unsound mind must, in cases of this character, be determined by the same tests which are applied in any case where it is sought to sct aside the contract or other act of the person alleged to be insane. It is universally held that a variation from a normal mental condition is not in itself enough to avoid every act. The mental defect or derangement must be one having a direct bearing upon the particular act which is brought in question." Dunphy v. Dunphy, I6r Cal. 380, 383, II9 Pac. 512, 513 (I9Ix) (italics added). "A marriage contract will be invalidated by the want of consent of capable persons. It requires the mutual consent of two persons of sound mind, and if at the time a marriage ceremony is performed one of the partics is mentally incapable of giving an intelligent consent to what is done, with an understanding of the obligations assumed, the solemnization is a mere idle ceremony, conferring no right and lcaving the status of cach party unchanged." Hagenson v. Hagenson, 258 Ill. 197, 198-199, 101 N.E. 606, 607 (1913) (italics added).

Accord: McClure v. Donovan, 86 Cal. App. 2d 747, I95 P. 2d 9or (1948); Elzey v. Elzcy, I Houst. 308 (Del. r857); Pyott v. Pyott, x9r Ill. 280, 6r N.E. 88 (rgor); Gellert v. Busman's Adm'r, 239 Ky. 328, 39 S. W. 2d 5 II (193I); Inhab. of St. George v. City of Biddeford, 76 Me. 593 (1885); Montgomery v. U'Nertle, I 43 Md. 200, I22 Atl. 357 (I923), discussed in Note, 8 MiNN. L. REv. I69 (I924); Elfont v. Elfont, I6r Md. 458, 157 Atl. 74I (1932); Van Haaften v. Van Haaften, 139 Mich. 479, 102 N. W. 989 (1905); Lewis v. Lewis, 44 Minn. 124, 46 N. W. 323 (1890); Ward v. Dulaney, 23 Miss. 410 (I852); Chapline v. Stone, 77 Mo. App. 523 (I898); Guthery v. Ball, 206 Mo. App. 570, 228 S. W. 887 (I92I); Westermayer v. Westermayer, 216 Mo. App. 74, 267 S. W. 24 (1924); Murphy v. La Chapelle, 95 Mont. 36, 24 P. 2 d 131 (1933); Kutch v. Kutch, 88 Ncb. x14, 129 N. W. 169 (1910); Svanda v. Svanda, 93 Neb. 404, I40 N. W. 777 (I9ז3); McNee v. McNee, 49 Nev. 90, 237 Pac. 534 (1925); True v. Ranney, 2I N. H. 52, 53 Am. Dec. I64 (1850); Kern v. Kern, 5I N. J. Eq. 574, 26 Atl. 837 (I893); Buffum v. Buffum, 86 N. J. Eq. II9, 97 Atl. 256 (I916); Meckins v. Kinsella, 152 App. Div. 32, 136 N.Y.S. 806 (Ist Dep't I912); Kemmelick v. Kemmelick, $11_{4}$ Misc. 198, I86 N. Y. S. 3 (Sup. Ct. I92I); Ross v. Ross, r75 Okla. 663, 54 P.2d 6II (1936); De la Montanya v. De la Montanya, x3x Ore. 23, 28I Pac. 825 (1929); Schneider v. Rabb, 100 S. W. 163 (Tex. Civ. App. I907); Hempel v. Hempel, 174 Wis. 332 , I8I N. W. 749 (I92I). In Bloom v. Bloom, 76 N. Y. S. $2 d 890$ (Sup. Ct. 1947), a complaint alleging that the wife was afflicted with a mental infirmity or disorder, as a result of which she "could not fully discharge her marital duties or functions," was dismissed as stating only conclusions of law. 
on the capacity to marry. It is familiar law in all matters involving mental incompetency that the mind's capacity must be judged with reference to the particular act involved: capacity to make a will, capacity to commit a crime, capacity to buy and sell-each involves a different quality and degree of mental keenness. ${ }^{7}$ So, here, the ability to think with sufficient clearness about marriage may or may not accompany the capacity to think clearly about other contracts.

As a matter of public policy, as well as of legal analogy, a different, and perhaps less severe, test seems to be called for in the marriage cases. In matters involving ordinary commercial dealings, the incompetent may achieve the ultimate benefits by virtue of the intervention of a guardian; but a guardian cannot contract a marriage for his ward. Hence one under guardianship must either stay single, or be allowed to marry in spite of his inability to engage in business. For the numerically considerable group of mentally weak persons, whose estates are controlled by guardians but who are permitted to go at large in the community, a legal prohibition on marriage would simply result in fornication, temporary liaisons, and similar socially undesirable practices. Consequently, the law wisely has permitted such persons to marry if it appeared that, concerning that particular kind of relationship, they had a reasonably intelligent attitude. ${ }^{8}$

Further, merely to state in words a "test" of mental capacity is by no means to solve the problem. In the first place, it must be remembered that this issue is one of capacity to have the proper understanding; hence mere lack of appreciation of the nature of marriage, arising from youth or ignorance, will not affect the marriage. ${ }^{9}$ Further, to understand the nature of marriage and its duties and responsibilities is a problem that has taxed the abilities of generations of able scholars; clearly, then, we expect here only a minimum of appreciation of those matters in their most general aspects. ${ }^{10}$ The result is to leave each case to be decided very much on its own facts, with the decision of the trier of the facts largely controlling. ${ }^{11}$

' On this point, in addition to the holdings in the cases cited in the preceeding footnotes, consult the excellent analysis in Kern v. Kern, 5 I N. J. Eq. 574, 26 Atl. 837 (I893); and consult Note, 14 ST. Louis L. REv. 422 (I929).

a "If the powers of his mind had been so far affected by disease or the decay of his faculties as to render him incapable of knowing the effect of the act he was about to perform, and of intelligently consenting to the ceremony, then there was an incapacity on his part to contract. On the other hand, even if his understanding was weak, still, if his capacity remained to see things at the time in their true relations, and to form correct conclusions, the contract of marriage would be valid. . . ." Baughman v. Baughman, 32 Kan. 538, 545, 4 Pac. I003, I007 (1884). Accord: Johnson v. Johnson, 214 Minn. 462,8 N. W. $2 d 620$ ( 2943 ).

${ }^{\circ}$ Green v. Green, 77 Fla. Ior, 80 So. 739 (19r9); Adams v. Scott, 93 Neb. 537, 14I N. W. 148 (1913).

10 "He need not have understood all the duties, obligations and responsibilities which the marriage relation imposed upon him, because that rule would probably render void many marriages in this state ... But he should have had at the time sufficient mental capacity to enable him to understand the nature of the marriage relation, the nature of the marriage contract, and to understand that upon himself he took with it all the duties, obligations and responsibilities which the law would impose upon him as a result of that contract on his part, whatever they were." Inhab. of St. George v. City of Biddeford, 76 Me. 593, 597 (1885) (italics supplied).

And see Kern v. Kern, 5 I N. J. Eq. 574, 26 Atl. 837 (1893).

${ }^{11}$ For the reasons stated in the text, only a detailed examination of each case will show what conduct and condition is likely to affect the judgment of a court. There is here given a selective list 
In a few cases, marriage has been attacked on the ground that the party was, at the time of the ceremony, under the influence of drugs or liquor. If the effect of such intoxicants was to make the person unconscious of what was going on, no marriage resulted, since there was not even an appearance of assent. ${ }^{12}$ But if intoxication had not proceeded that far, then the courts have treated it as merely a special

of cases in which such evidentiary matters have been sufficiently discussed to make them helpful as guides in future litigation.

Insufficient capacity: Dunphy v. Dunphy, I6I Cal. 380, II9 Pac. 512 (1911) (weakness of mind coupled with habitual intoxication); Orchardson v. Cofield, I7r Ill. 14, 49 N. E. 197 (1897) (weakness of mind, extreme belief in spiritualism, and fraud); Pyott v. Pyott, 19I Ill. 280, 6r N. E. 88 (1901); Chapline v. Stone, 77 Mo. App. 523 (1898); Guthery v. Ball, 206 Mo. App. 570, 228 S. W. 887 (Ig21) (but cf., involving the same marriage, Guthery v. Wetzel, 205 Mo. App. 664, 226 S. W. 626 (I920)); Westermayer v. Westermayer, 216 Mo. App. 74, 267 S. W. 24 (I924); McNee v. McNee, 49 Nev. 90, 237 Pac. 534 (I925); True v. Ranney, 2I N. H. 52, 53 Am. Dec. I64 (1850); Buffum v. Buffum, 86 N. J. Eq. II9, 97 Atl. 256 (IgI6); Jaques v. The Public Adm'r, I Bradf. 499 (N. Y. I85I) (death bed marriage); Whitney v. Whitney, I2x Misc. 485,201 N. Y. S. 227 (Sup. Ct. 1923), discussed in Notes, 33 YALE L. J. 334 (1924) and 24 Cor. L. REv. 95 (I924) (incurable dementia praecox); Crump v. Morgan, 38 N. C. (3 Ired. Eq.) 9r, 40 Am. Dec. 447 ( 1843 ) (total lunacy); Goodheart v. Ransley, II Ohio Dec. Rep. 655, 28 WrLY. LAw But. 227 (I892) (where there had been adjudication of insanity, though the evidence seems to show that party knew he was being married and understood at least the physical rights and obligations)); Foster, Adm'r v. Means, I Speers' Eq. 569, 42 Am. Dec. 332 (S. C. 1844) (lack of reasoning powers); Counts v. Counts, I6r Va. 768, I72 S. E. 248 (1934).

Sufficient capacity: Smith v. Smith, I4I Ala. 590, 37 So. 638 (1904); Hagenson v. Hagenson, 258 111. 197, 101 N. E. 606 (1913); Flynn v. Troesch, 373 Ill. 275, 26 N. E. 2d 91 (1940) (arteriosclerosis); Baughman v. Baughman, 32 Kan. 538, 4 Pac. 1003 (1884) (brain paralysis); Gellert v. Busman's Adm'r, 239 Ky. 328, 39 S. W. 2d 511 (I93I) (previous adjudication of insanity, but party had been successfully employed and happily married until her death); Elfont v. Elfont, I6r Md. 458, I57 Atl. 741 (1932) (party was drawing government compensation for dementia praccox); Anonymous, 2 I Mass. (4 Pick.) 32 ( 1826 ) ("the fact of a party's being able to go through the marriage ceremony "with propriety was prima facie evidence of sufficient understanding to make the contract"); Van Haaften v. Van Haaften, I39 Mich. 479, 102 N. W. 989 (1905) (delusions that party was visited by personal devils and by angels); Lewis v. Lewis, 44 Minn. 124,46 N. W. 323 (189o) (kleptomania); Ward v. Dulaney, 23 Miss. 410 (1852) (hysteria); Powell v. Powell, 27 Miss. 783 (I854); Smith v. Smith, 47 Miss. 2 I (1872); Wilson v. Wilson, I04 Miss. 347,6 I So. 453 (1913); Payne v. Burdette, 84 Mo. App. 332 (1900) (prior adjudication of insanity); Henderson v. Henderson, 14I Mo. App. 540, 126 S. W. 203 (1910); Henderson v. Ressor, 265 Mo. 718 , I78 S. W. I75 (1915) writ of error dismissed, 248 U. S. 536 (19r8); Guthery v. Wetzel, 205 Mo. App. 664, 226 S. W. 626 (rg20) (but cf. Guthery v. Ball, 206 Mo. App. 570, 228 S. W. 887 (x92I), involving the same marriage); Murphy v. LaChappeile, 95 Mont. 36, 24 P. 2d I3I (1933); Kutch v. Kutch, 88 Neb. I14, 129 N. W. I69 (1910); Svanda v. Svanda, 93 Neb. 404 , 140 N.W. 777 (1913); Kern v. Kern, 51 N. J. Eq. 574, 26 Atl. 837 (1893); Brainen v. Brainen, 79 N. J. Eq. 270, 82 Atl. 327 (Igr2) (party had been released as cured from a sanitarium for mental cases); Banker v. Banker, 63 N. Y. 409 (1875); Meekins v. Kinsella, 152 App. Div. 32, 136 N. Y. S. 806 (Ist Dep't I912) (paranoia); Kemmelick v. Kemmelick, I14 Misc. 198, 186 N. Y. S. 3 (Sup. Ct. I92I) (delusions); Weinberg v. Weinberg, 255 App. Div. 366, 8 N. Y. S. 2d 34I (4th Dep't 1938); McCleary v. Barcalow, 6 Ohio C. C. 481,3 Ohio Dec. 547 (189r) (guardianship); Ross v. Ross, I75 Okla. 663, 54 P. 2d 611 (1936) (semble); Coleman v. Coleman, 85 Ore. 99, I66 Pac. 47 (rgr7); De la Montanya v. De al Montanya, r3r Ore. 23, 28r Pac. 825 (rg29); Clcment v. Mattison, 37 S. C. L. (3 Rich. L.) 93 (1846); Cole v. Cole, 37 Tenn. (5 Sneed) 57, 70 Am. Dec. 275 (1857); Hempel v. Hempel, I74 Wis. 332, I8I N. W. 749 (r92I) (weakmindedness); Roether v. Roether, 180 Wis. 24 , I91 N. W. 576 (1923) (guardianship); Kuchne v. Kuehne, 185 Wis. 195, 201 N. W. 506 (r924) (excessive jealousy).

${ }^{12}$ Hamlet v. Hamlet, 242 Ala. 70, 4 So. 2d 9or (I94I); Baxter v. Rogers, 195 Ga. 274, 24 S. E. 2d 52 (1943); Martin v. Martin, I5I Fla. 676, 26 So. 2d 90I (1946); Montgomery v. U'Nertle, I43 Md. 200, 122 Atl. 357 (1923); Gillett v. Gillett, 78 Mich. 184, 43 N. W. 1 10r (1889); Sloane v. Kane \& Grant, ro How. Pract. 66 (N. Y. 1854); see Elzey v. Elzey, I Houst. 308 (Del. 1857); Prine v. Prine, 36 Fla. 676, I8 So. 78I (I895); Barber v. People, 203 Ill. 543, 68 N. E. 93 (1903); Waughop v. Waughop, 82 Wash. 69, I 43 Pac. 444 (19r4). 
manifestation of mental incompetency, to be judged by the same tests. In other words, if the intoxication had rendered the party, for the time, incapable of understanding the nature of the relation into which he purported to enter, or of appreciating its duties and responsibilities, then a valid marriage had not resulted; but if his incapacity fell short of that standard, the marriage was not open to attack. ${ }^{13}$ Of course, the fact of intoxication may have an evidentiary value in determining whether alleged fraud or duress actually operated on a particular person.

Two obstacles stand in the way of one who would attack a marriage on the ground of the mental incapacity of one party thereto: There is a general presumption of sanity; ${ }^{14}$ and there is an even stronger presumption in favor of the validity of any marriage whose status is questioned..$^{15}$ Hence, the burden of proof on the issue of mental capacity is on whichever party to the litigation seeks to attack the marriage, ${ }^{16}$ and this burden must be maintained by clear and convincing proof before a court will rule against validity of the marriage. ${ }^{17}$

Since lack of mental capacity affects marriage only in so far as it negatives the existence of an intent to become married, ${ }^{18}$ it follows that only the condition at the time of the ceremony is important. ${ }^{19}$ Hence, an adjudication of insanity after the marriage raises no presumption of invalidity, ${ }^{20}$ though, under the rules of evidence

${ }^{13}$ Dunphy v. Dunphy, I6I Cal. 380, IIg Pac. 512 (IgrI), discussed in Note, xo Mrch. L. REv. 500 (1912); Elzey v. Elzey, I Houst. 308 (Del. 1857); Prine v. Prine, 36 Fla. 676, 18 So. 781 (1895); Barber v. People, 203 Ill. 543, 68 N. E. 93 (1903); Montgomery v. U'Nertle, r43 Md. 200, I22 Atl. 357 (1923), discussed in Note, 8 Minn. L. Rev. 169 (I924); McNee v. McNee, 49 Nev. 90, 237 Pac. 534 (I925); Selah v. Selah, 23 N. J. Eq. I85 (1872); Clement v. Mattison, 37 S. C. L. (3 Rich. L.) 93 (1846); see: Anderson v. Hicks, I50 App. Div. 289, 134 N. Y. S. Ior8 (2d Dep't I912); McCleary v. Barcalow, 6 Ohio C. C. $48 \mathrm{r}, 3$ Ohio Dec. 547 (1891); Imhoff v. Witmer's Adm'r, 31 Pa. St. (7 Cascy) 243 ( 1858 ); and consult Note, 34 L. R. A. 87 (I905).

14 I Burr W. Jones, The Law of Evidence in Civil CaSes 104, $\$ 59$ (4th ed. 1938); and see: Woodworth v. Woodworth, 27 I Mass. 398, I7I N. E. 43I (1930); Powell v. Powell, 27 Miss. 783 (I854).

${ }^{15}$ I BuRR W. Jones, The Law of Evidence In Crvil Cases 150-151, $\$ 86$ (4th ed. 1938); and see: Flynn v. Troesch, 373 Ill. 275, 26 N. E. 2d 9I (1940); Castor v. Davis, 120 Ind. 231, 22 N. E. IIo (1889); Langdon v. Langdon, 204 Ind. 321, 183 N. E. 400 (1932); Note, 67 U. S. L. Rev. 27x (1933).

${ }^{16}$ Flynn v. Troesch, 373 Ill. 275, 26 N. E. 2d 9I (1940); Woodworth v. Woodworth, 27I Mass. 398, I7I N. E. 43 I (1930); Banker v. Banker, 63 N. Y. 409 (1875); De la Montanya v. De la Montanya, I3I Ore. 23, 28I Pac. 825 (I929); Nonnemacher v. Nonnemacher, I59 Pa. 634, 28 Atl. 439 (I894); but see Weinberg v. Weinberg, 255 App. Div. 366, 8 N. Y. S. 2d 34.x (4th Dep't 1938).

${ }^{17}$ In addion to direct statements to that effect in the cases cited in the three preceding footnotes, this rule is applied in the group of cases cited in note 11 supra.

"But this contract is so important in its consequences, the rights, duties, obligations and responsibilities which it creates and imposes are of so delicate and important a character, involving not only the happiness, well-being and respectability of the parties themselves, but also the honor and peace of families, that the policy of the law requires courts of justice to sustain and uphold it, unless the proof be entirely clear and satisfactory, leaving no reasonable doubt upon the mind of the incapacity of the party and the consequent invalidity of the marriage." Ward v. Dulaney, 23 Miss. 4IO, 4I4 (I852).

${ }^{18}$ It should be here noted that epilepsy, which is, of course, a mental disease, is treated in law, where its existence does affect the capacity to marry, as a lack of physical and not of mental capacity.

In a few jurisdictions, laws exist against the marriage of "feebleminded" persons, except where the woman is over the age of forty-five. Such laws have been held to be matters of eugenics rather than of capacity to assent to marry, and are not among the rules here under discussion. Consult: Lau v. Lau, 8I N. H. 44, I22 Atl. 345 (1923); Schoolcraft v. O'Neil, 8I N. H. 240, I23 Atl. 828 (I924).

${ }^{10}$ Consult the cases cited, infra, notes 20 and 23; and see Barber v. People, 203 Ill. 543, 68 N. E. 93 (1903).

${ }^{10}$ Smith v. Smith, 47 Miss. 2 I I (I872); Slais v. Slais, 9 Mo. App. 96 (I880); Kern v. Kern, 51 N. J. Eq. 574, 26 Atl. 837 (r893); Brainen v. Brainen, 79 N. J. Eq. 270, 82 Atl. 327 (I9'12); Banker 
which permit inquiry into the party's state over a relatively wide period of time, such an adjudication is normally admissible for whatever inferences may be drawn from it. ${ }^{21}$ But where there has been an adjudication of general insanity prior to the marriage, and that adjudication still stands at the date of the marriage, the one who would attack validity can then rely on the presumption that a condition once shown to exist continues ${ }^{22}$ and proof of such an adjudication will make out a prima facie, but a rebuttable, case of incapacity to marry. ${ }^{23}$ That such a presumption should be a rebuttable one follows logically from the rule, previously discussed, ${ }^{24}$ that capacity to marry depends on the ability to understand the marriage contract and not necessarily on the ability to do commercial business. In addition, the policy of sustaining as valid all apparent marriages so far as possible leads the courts to give an increased credence to the argument that there had been an improvement in mental state between the date of adjudication and the date of marriage.

At common law, and generally today. except where statutory provisions have effected a different rule, ${ }^{25}$ the marriage of one lacking in mental capacity was treated as totally void, and thus open to collateral attack and to attack after the death of either party. ${ }^{26}$ However, this common law rule exists now in only a few jurisdic-

v. Banker, 63 N. Y. 409 (1875); Forman v. Forman, 24 N. Y. S. 917, 53 N. Y. St. Rep. 639 (Sup. Ct. 1893); Meckins v. Kinsella, 152 App. Div. 32, 136 N. Y. S. 806 (Ist Dep't r9r2); Nonnemacher v. Nonnemacher, 159 Pa. 634, 28 Atl. 439 (I894).

212 John H. Wigmore, A Treatise on the Anglo-American System of Evidence in Trials at Conmon LAw 25, $\$ 233 ; 5$ id. at 678-679, \$167I.

229 id. at $46 \mathrm{r}, \$ 2530$.

${ }^{23}$ Castor v. Davis, 120 Ind. 23 r, 22 N. E. IIo (1889); Langdon v. Langdon, 204 Ind. 321, 183 N. E. 400 (1932), discussed in Note, 67 U. S. L. REv. 27 I (1933); Gellert v. Busman's Adm'r, 239 Ky. 328, 39 S. W. 2d 51 I (1931); Smith v. Smith, 47 Miss. 21 I (1872); Parkinson v. Mills, I72 Miss. 784, I59 So. 651 (1935); Payne v. Burdette, 84 Mo. App. 332 (I900); Weinberg v. Weinberg, 255 App. Div. 366, 8 N. Y. S. 2d 34r (4th Dep't 1938 ), discussed in Note, 8 Fond. L. Rev. 273 (1939); McCleary v. Barcalow, 6 Ohio C. C. 481,3 Ohio Dec. 547 (I89r); Ross v. Ross, 775 Olila. 663, 54 P. 2d 6II (1936); Nonnemacher v. Nonnemacher, r59 Pa. 634, 28 Atl. 439 (1894); Keys v. Norris, 27 S. C. Eq. (6 Rich. Eq.) 388 (1854); Roether v. Roether, I80 Wis. 24, I9r N. W. 576 (1923). It is stated in Strahorn, Void and Voidable Marriages in Maryland and Their Annulment, 2 MD. L. REv. 21I, 242-244 (1938), that, in Maryland, by virtue of the continued effect of I5 Geo. II, c. 30, marriages of adjudicated lunatics are totally void by the mere force of the adjudication.

${ }^{24} \mathrm{Cf}$. especially the cases cited in note 5 , stupra.

${ }^{26}$ Consult Notes, I.R.A. I9r6C 700 (1916); 25 L.R.A. 800 (1905); 15 Am. Dec. 368 (1910); and consult: Strahorn, Void and Voidable Marriages in Maryland and Their Annulment, 2 Mo. L. Rev. $2 x I, 242-244$ (I938).

The wide variety of statutory provisions on the subject are collected and analyzed in I CHestrer G. Vernier, American Family Laws x88-196, \$4I (1931).

${ }^{23}$ Sothern v. United States, I2 F. $2 \mathrm{~d} 936$ (D. Ark. I926), discussed in Note, 36 YALE L. J. 577 (1927); Rawdon v. Rawdon, 28 Ala. 565 (1856); Sibley v. Kennedy, 224 Ala. 354, I40 So. 552 (1932); Williams v. Williams, 83 Colo. I80, 263 Pac. 725 (1927); Kuehmsted v. Turnwall, I02 Fla. 1180, 138 So. 775 (I932); Bell v. Bennett, 73 Ga. 784 (1884); Medlock v. Merritt, 102 Ga. 212, 29 S. E. I85 (1897); Orchardson v. Cofield, I7I Ill. I4, 49 N. E. I97 (1897); Pyott v. Pyott, 19r Ill. 280, 6r N. E. 88 (1901), but of. Barber v. People, 203 Ill. 543, 68 N. E. 93 (1903) (intoxication makes marriage only voidable, not void); Wiley v. Wiley, 75 Ind. App. 456, 123 N. E. 252 (1919); Langdon v. Langdon, 204 Ind. 32I, 183 N. E. 400 (1932), discussed in Note, 8 IND. L. J. 445 (1933), but cf. Bruns v. Cope, $x 82$ Ind. 289, r05 N. E. 471 (I914), which presumably is no longer good law; Floyd County v. Wolfe, I38 Iowa 749, II7 N. W. 32 (rg08); Powell v. Powell, i 8 Kan. 37I, 26 Am. Rep. 774 (1877); Jenkins v. Jenkins' Heirs, 2 Dana 102, 26 Am. Dec. 437 (Ky. 1833); Johnson v. Sands, $245 \mathrm{Ky} .529,53$ S. W. 2d 929 (x932); Inhab. of Unity v. Inhab. of Belgrade, 76 Me. 419 (1884); Inhab. of St. George v. City of Biddeford, $76 \mathrm{Me}$. 593 (1885); Inhab. of Middleborough v. Inhab. of Rochester, 12 Mass (12 Tyng) $36_{3}$ (1815); Ward v. Dulaney, 23 Miss. 4 10 (1852); Guthcry v. Ball, 
tions. $^{27}$ In a few states, express prohibitions on collateral attack exist; ${ }^{28}$ in others,

206 Mo. App. 570, 228 S. W. 887 (I92I), but of. Guthery v. Wetzel, 205 Mo. App. 664, 226 S. W. 626 (1920); Wightman v. Wightman, 4 Johns. Ch. 343 (N. Y. I820); Johnson v. Kincade, 37 N. C. (2 Ired. Eq.) 470 (I843); Crump v. Morgan, 38 N. C. (3 Ired. Eq.) 91, 40 Am. Dec. 447 (I843); Waymire v. Jetmore, 22 Ohio St. $27 \mathrm{I}$ ( 1872 ); Heath v. Heath, 25 Ohio N. P. [N.s.] 123 (1924), but cf. McCleary v. Barcalow, 6 Ohio C. C. 48I, 3 Ohio Dec. 547 (I89x); Newlin's Estate, 23r Pa. 3I2, 80 Atl. 255 (IgrI); Foster, Adm'r v. Means, I Speers' Eq. 569, 42 Am. Dec. 332 (S. C. I844).

In addition to the cases cited above, in which the courts directly passed on the issue of void versus voidable marriages, there are a considerable number of cases in which collateral attacks, or attacks after death, have been permitted without question of the right so to do. Consult: Hagenson v. Hagenson, 258 Ill. 197 , ror N. E. 606 (x913); Flynn v. Troesch, 373 Ill. 275, 26 N. E. $2 d$ 91 (r940); Castor v. Davis, I20 Ind. 23x, 22 N. E. Iro (1889); Baughman v. Baughman, 32 Kan. 538, 4 Pac. 1003 (1884); Gellert v. Busman's Adm'r, 239 Ky. 328, 39 S. W. 2d 5II (I93I); Inhab. of Atkinson v. Inhab. of Medford, 46 Me. 510 (I859); Inhab. of Winslow v. Inhab. of Troy, 97 Me. 130, 53 Atl. x008 (I902); Banker v. Banker, 63 N. Y. 409 (1875); Nonnemacher v. Nonnemacher, 159 Pa. 634, 28 Atl. 439 (1894); Keys v. Norris, 27 S. C. Eq. (6 Rich. Eq.) 388 (1854).

The decisions in three states suggest some local peculiarities which deserve special mention:

In Georgia, although it was squarely held in Bell v. Bennett, $73 \mathrm{Ga} .784$ ( 1884 ), that the marriage of an insane person was void and subject to collateral attack in an action for a widow's allowance, still, in Crawford v. Crawford, I39 Ga. 535, 77 S. E. 826 (1913), the court permitted a direct suit for a declaration of nullity, brought by the heirs after death, on the theory that a collateral attack on the marriage in probate proceedings would not have been permitted.

In Missouri, the court, in Payne v. Burdette, 84 Mo. App. 332 (1900), assumed, without argument, that the marriage was void; then, in Guthery v. Wetzel, 205 Mo. App. 664, $226 \mathrm{~S}$. W. 626 (I920), the court refused to permit a collateral attack on a marriage in a probate proceeding to secure the widow's appointment as administratrix; but, in a second case involving the same marriage, the same court allowed a direct suit by the heirs to have the marriage decreed void, distinguishing the earlier case in part on the theory that even a void marriage could not be collaterally attacked, though it could be attacked after death. Guthery v. Ball, 206 Mo. App. 570, 228 S. W. 887 (I92I).

In North Carolina, the court early declared the marriage of an incompetent to be void. Johnson v. Kincade, 37 N. C. (2 Ired. Eq.) 470 ( 1843 ); Crump v. Morgan, 38 N. C. (3 Ired. Eq.) 9I, 40 Am. Dec. 447 ( 1843 ). Twelve years later, in Williamson v. Williams, 56 N. C. 446 (1857), the court indicated a doubt as to the permissibility of a collateral attack and solved the problem by staying such a suit pending the bringing and determination of a direct annulment suit. Dictum in State ex rel. Setzer v. Setzer, 97 N. C. 252 , I S. E. 558 (1887), again doubted the existence of a right to collateral attack. This was followed, in 1897 , by a short and not too well reasoned opinion, in Sims v. Sims, I2I N. C. 297,28 S. E. 407 (1897), declaring that, while such marriages were void and could be attacked after death, still a collateral attack was not to be permitted. The last step is dicta in Watters v. Watters, I68 N. C. $4 \mathrm{rI}, 84$ S. E. 703 (r915), where a direct suit for annulment had been brought, that the marriage was voidable and not void.

${ }^{27}$ In seven states (Alabama, Arizona, Colorado, Florida, Maryland, New Mexico, and Texas) there is no statute on the subject. I Chester G. Vernier, AMrerican Family Laws I89, \$4I (1931). (This work also lists Louisiana as having no statute, but this is an error. Consult Ducasse's Heirs v. Ducasse, I20 La. 73I, 45 So. 565 (I908), and the statute there construed). Of these seven states, presumably five retain the common law rule. Eminent authority has stated the rule in Maryland to be that the marriage of an adjudicated lunatic is totally void, but that the marriage of an unadjudicated lunatic or incompetent is voidable only. Strahorn, Void and Voidable Marriages in Maryland and Their Annulment, 2 M. L. REv. 2II, 242-244 (1938). In Texas, although no statute exists, the court has repudiated the common law rule and adopted the rule of voidability. Carter v. Green, 64 S. W. $2 d$ 1069 (Tex. Civ. App. r933), expressly declining to follow contrary dicta in Holland v. Riggs, 53 Tex. Civ. App. 367 , 116 S. W. 167 (1909).

Twelve states (Georgia, Indiana, Kentucky, Maine, Michigan, Missouri, Montana, Nebraska, New Hampshire, Rhode Island, Utah, and Wyoming), expressly declare such marriages to be "void." However, the courts in those states have not always taken such declarations literally. The Georgia and Missouri cases are discussed supra in note 26 to this section. In Nebraska and New Hampshire, the courts restrict the statutory declaration to the limited class ("Iunatics") expressly named in the statutes. Aldrich v. Steen, 7 I Neb. 33,98 N. W. 445,100 N. W. 3Ir (I904); Lau v. Lau, 8I N. H. 44, r22 Atl. 345 (r923). Only in Michigan and in Wyoming are the statutory declarations sufficiently strong to make the rule clear in the absence of judicial construction.

${ }^{28}$ Massachitsettr: consult: Inhab. of Goshen v. Inhab. of Richmond, 86 Mass. (4 Allen) 458 (I862); Woodworth v. Woodworth, 27 I Mass. 398, I7I N. E. 43I (1930); and North Carolina (but see the North Carolina cases discussed supra, note 26 to this section). 
procedural statutes on annulment, providing that the marriage of one lacking in mental capacity shall be void "from the time it is so decreed," or using similar language, have been construed as making such marriages voidable only; ${ }^{20}$ in other states the courts have looked to statutes which, in terms, listed certain marriages as "void" and, applying the rule of interpretation known as "expressio unius," have concluded that the marriages of incompetents, not being so listed, were voidable merely; ${ }^{30}$ in still other states, the courts have been influenced by the fact that the statutes on annulment limited either the persons who could bring such suits or the time within which they could be brought. ${ }^{31}$

On principle, and apart from the considerations of statutory construction above discussed, there is much to be said for both rules. In favor of the doctrine of total voidness, it is urged: (a) that it follows logically from the fact that mental incompetency makes impossible the existence of the fundamental essential of marriagecontractual assent; $;^{32}$ (b) that any other rule opens the door to fraud and abuse, by upholding a marriage, kept secret during the lifetime of the incompetent, which will then enrich a designing spouse at the expense of legitimate heirs; ${ }^{33}$ (c) that, even if the marriage is attacked directly during the lifetime, the adventurer or adventuress will secure an illicit advantage through the interim support. Against such arguments, it has been said: (a) that, since mental incompetency is always difficult to determine, collateral attacks and attacks after the death of a spouse should be barred in favor of direct attacks, while both spouses are living, with their opportunity for examination of the claimed incompetent; and (b) that it is socially undesirable to allow strangers to attack an apparent marriage status, and even more undesirable to allow a status, accepted without question while the parties thereto were alive, to be upset ex post facto by persons usually motivated only by a desire to inherit property at the expense of the surviving spouse. ${ }^{\mathbf{3 4}}$

When we turn to the cases involving the "voluntary" character of the consent, questions of policy become even more apparent than in the cases of "insanity." The cases of "Duress" are not especially important, since the courts have applied what is, in

${ }^{20}$ Arkansas, District of Columbia, Nevada, New York, Oregon, Virginia, and West Virginia.

These statutes are so construed and applied in: Hastings v. Douglass, 249 Fed. 378 (D. W. Va. 1918); Mackey v. Peters, 22 App. D. C. 34I (1903); Henderson v. Ressor, 265 Mo. 7I8, I78 S. W. I75, writ of error dismissed, 248 U. S. 536 (rgr8) (applying the Arkansas statute); Sturgis v. Sturgis, 5I Ore. Io, 93 Pac. 696 (1908); Cornwall v. Cornwall, I60 Va. 183, I68 S. E. 439 (1933).

${ }^{30}$ Estate of Gregorson, I60 Cal. 21, II6 Pac. 60 (IgrI); Dunphy v. Dunphy, 161 Cal. 87, II8 Pac. 445 (I9II); Wolf v. Gall, 32 Cal. App. 286, I63 Pac. 346 (I917); Mackey v. Peters, 22 App. D. C. 341 (1903); Ellis v. Ellis, 152 Miss. 836, II9 So. 304 (1928), discussed in Note, 77 U. op PA. L. Rev. $8 \mathrm{r}$ (1929); White v. Williams, I54 Miss. 897 , I24 So. 64 (1929), affd. on second appeal, 'x59 Miss, 732, I32 So. 573 (193I), discussed in Note, 29 Mrer. L. Rev. I089 (I93I); In re DeConza's Estate, 13 N. J. Misc. 4I, I76 Atl. 192 (1934); Stuckey v. Mathes, 24 Hun 46I (N. Y. I88I); Ross v. Ross, I75 Okla. 663, 54 P. 2d 6rI (1936); Wiser v. Lockwood's Estate, 42 Vt. 720 ( $(2870)$.

${ }^{3 x}$ Consult, inter alia: Estate of Gregorson, 160 Cal. 21, I16 Pac. 60 (rgri); Hoadley v. Hoadley, 244 N. Y. 424,155 N. E. 728 (1927).

${ }^{32}$ Consult: Jenkins v. Jenkins' Heirs, 2 Dana r02, 26 Am. Dec. 437 (Ky. 1833).

ss Consult: Jaques v. The Public Adm'r, I Bradf. 499 (N. Y. I85I).

${ }^{34}$ The best discussions of the arguments against the rule of total voidness are in: White $\mathrm{v}$. Williams, I54 Miss. 897, 124 So. 64 (1929), aff'd on second appeal, 159 Miss. 732, 132 So. 573 (1931), discussed in' Note, 29 Mrch. L. REv. ro89 (r93 I); Carter v. Green, 64 S. W. 2 d ro69 (Tex. Civ. App. 1933). 
essence, the same concept as they use for any contract case. But when the apparent consent was obtained by fraud, we come squarely against deep-seated ideas. As we all know, the English courts apply a concept of "Caveat Suitor" so firmly that annulment for fraud, in our American sense, is unknown in that country. ${ }^{35}$ In the United States, the policy considerations vary from the extreme liberalism of the New York courts, to the ultra-conservatism of Massachusetts. It is, however, safe to say that -at least outside of New York-the American courts universally apply in annulment cases an objective rather than a subjective standard of fraud. The classic phraseology is that fraud, to be ground for annulment, must go to the "essentials" of marriagei.e., that it must affect the possibility of normal marital cohabitation. The case law has come to make the meaning of this concept rather specific. Concealed pregnancy by another man (at least in the absence of pre-marital intercourse with the plaintiff), concealment of venereal disease, or of sterility, and a concealed intent not to permit normal intercourse or to maintain a normal home-these represent, for practical purposes, the limits of essential fraud. False claims of pregnancy, concealment of previous bad character, or of ill-health, lack of love and affection-these, except in rare and extreme instances, will afford no ground for relief. ${ }^{36}$

II

\section{Capacity to Marry}

As has been said above, the cases that fall under this heading involve not the law of annulment, but the law of marriage. It is the latter law which determines the age for marriage, the effect of blood relationship, of race, of impotency and sterility, of disease, and of previous marital status. Once the policy decisions on those points have been made, the rules which refuse to allow parties to violate this policy follow almost automatically.

III

\section{Critique}

In two places, it seems to me, there is room for real debate over the general American doctrines. One is over the general willingness to treat many of the rules relative to capacity-such as disease and non-age especially-as merely directory prerequisites to the issuance of a license and the consequent refusal to annul a marriage if, by hook or by crook, the party had procured a license from some indifferent or venal licensing officer. The other is the strict adherence to the concept of "essential" fraud.

The doctrine of "directory" provisions is the result of two things-first, the traditional attitude of an older time, that all statutory formalities were to be regarded as directory, and, second, the accident of legislative draftsmanship which expressed

${ }^{35}$ Moss v. Moss (1897) P. 263,66 L. J. P. I54, 77 L. T. 220,45 W. R. 635, I3 T. L. R. 459, discussed in Note, $4 \mathrm{x}$ SoL. J. 556 (1897).

${ }^{30}$ I have discussed the law of annulment for fraud, and its illustrations, at some length in another article-Kingsley, Fraud as a Ground for Annulment of a Marriage, I8 So. Calif. L. Rev. 213 (I945). I have not repeated the full documentation here. 
so much of our policy decisions concerning capacity for marriage in the form of prerequisites for a license. While common law marriage is steadily disappearing, the courts have not shown any tendency to depart from the subordinate canons of interpretation first created in order to promote the informal marriage. Probably, after so long a time, we cannot really expect the courts to reverse themselves on such matters. And yet, if we really want to prevent the immature and the diseased from contracting marriage, it would seem that something more than a pious injunction -avoidable by evasion at the counter of the license bureau-was required. But legislatures still go on, adding statutory requirements for certificates of freedom from serious disease, but, in the face of 150 years of statutory interpretation, placing these new provisions only in the sections on license prerequisites!

The rules about essential fraud on the other hand cannot be attributed to legislative action. They are court-created and court-administered in their entirety. But here, and for this very reason, the propriety of change is less clear. We would scarcely want a system in which every disappointed lover could slip out from under his or her marital responsibilities. Some recognition must be given to traditions of a courtier's self-adulation. Whatever a strict ethics may think of it, the idea of the "white lie" between prospective spouses is too old for a realistic legislator to ignore. In large part, the urge in textual writing for easier fraud annulments stems from a general modern unwillingness to take anything but the easiest way. Undoubtedly, the modern view which refuses to penalize the husband saddled with another man's child merely because of his own pre-marital incontinence ${ }^{37}$ is a wise relaxation, and much could be said for relief for the unfortunate spouse who has been tricked into marriage, against strong religious conviction, with a divorced person. ${ }^{38}$ But, in general, it does not seem very desirable to consider seriously much change in the law of annulment for fraud.

\section{ConcLusion}

In short, the grounds for annulment, as recognized in the United States generally, seem to be logical and reasonably practical, with the exception of the curious reluctance to afford sanctions for the evasion of positive policy-based rules on capacity for marriage. These rules, it is submitted, should be made effective, by express statutory provision, for the annulment of marriages contracted in violation of their terms.

${ }^{37}$ Cf. Amo v. Arno, 265 Mass. 282, 163 N. E. 861 (x928), discussed in Notes, 42 Harv. L. Rev. 108I (I929), 9 B. U. L. REv. 56 (1929), and I5 VA. L. Rev. 387 (1929); Gard v. Gard, 204 Mich. 255, I69 N. W. 908 (I9I8), discussed in Note, 28 YALE L. J. 516 (I919).

${ }_{\text {s8 }} \mathrm{Cf}$. Oswald v. Oswald, ${ }_{4} 6 \mathrm{Md}$. 313, I26 Atl. 81 (1924); Wells v. Talham, 180 Wis. 654,194 N. W. 36 (1923). 